\title{
The Standardization of American Schooling: Linking Secondary and Higher Education, 1870-1910 (Secondary Education in a Changing World)
}

\author{
Marc A. VanOverbeke \\ Palgrave Macmillan, New York, \$74.95, 240pp., ISBN: 0230606288
}

International Journal of Educational Advancement (2009) 9, 121-123. doi:10.1057/ijea.2009.30

Two key players of late nineteenthcentury education were university reformers and secondary school reformers. Marc VanOverbeke's new book, The Standardization of American Schooling, highlights the often-overlooked mutual relationship between the two institutions. The university reformers found themselves needing better-qualified students as they attempted to increase the function of college and universities as research centers. Further, the higher education reformers recognized the increasing social capital gained by their degree. The secondary school reformers saw themselves as a 'people's college' attempting to hold close the values of the common man. Together the two groups, VanOverbeke shows, forged the foundation for our current educational model.
This book provides a well-needed look into the relationship between higher education and secondary education in the late nineteenth century from national, state, and regional levels by examining why two separate types of educational institutions worked together to forge our modern educational structure. VanOverbeke provides a thorough beginning to an era rich with policy history.

To examine the relations between the institutional types, VanOverbeke gathers qualitative data, first relying heavily on detailed case studies, particularly in Michigan and at Harvard. He quickly expands from the Midwest, to the South, West, and then to the Northeast. He focuses on the contrasting ideas of each region, while at the same time 
noting the mutual need for separate institutional types to work together.

James Angell, the president of the University of Michigan from 1871 to 1909 , sought to make the University a national leader by increasing its population and standards by establishing an accreditation system for the state high schools. If the high school met accreditation, then a diploma from the school would suffice as entrance to the University. The accreditation system spread rapidly within the state, and then slowly to schools in other states.

As a result of the accreditation program, the secondary institutions enjoyed increased popularity and support; but they also struggled to balance the university course of study with a degree more applicable to life without a university degree. The secondary schools recognized that many students would never attend the university. Finally, by buying into the University's accreditation system, secondary school administrators yielded themselves to a lower level than the university, but solidified an important place in the modern educational hierarchy.

Michigan's accreditation model earned praise in most of the Midwest and West, while earning scorn from Harvard and Yale, which maintained that only individualized exams sufficiently indicated a student's readiness for higher education. The majority of Midwestern schools, including private schools like the University of Chicago and Northwestern sought to create accreditation models for secondary schools. New England faced several battles, in part because Harvard and Yale continued to focus on individualized entrance exams.
Only through long hours of collaboration and compromise at secondary, public and post-secondary levels did New England resolve itself to the modern methods developed in the Midwest.

Despite fraught battles between institutional types, VanOverbeke concludes that higher education's dominance came at a cost. Although Angell at Michigan and Charles Eliot at Harvard could gleefully remove preparatory departments from their expanding universities, the changes required the removal of some classical coursework such as Latin and the additions of modern courses like French. The secondary schools lost their status as the 'people's college,' but forced the colleges to change their curricula. No doubt, a great feat for secondary schools.

VanOverbeke portrays the adaptation as a result of university leaders trying to dominate the educational landscape by selling local school districts on the idea that being accredited eased the burden for all parties and helped send more students to college. Although VanOverbeke paints a fascinating picture, he never offers any empirical analysis of the results. Nor does he offer reasons for why the local school boards actually accepted the accreditation proposal from the universities. VanOverbeke opens the door for some thought provoking work in historical policy change. Obtaining empirical data and finding explanatory variables for why schools accepted accreditation, ought to be the next step.

When dealing with education in the late nineteenth century, we expect to see familiar actors. One might hope, in a book of this nature, to 
meet new secondary school characters. VanOverbeke relied too heavily on the classical characters of Angell and Eliot. Presidents from other institutions received cameos at best - a problem when trying to explain the shift in schooling at a national level.

Anecdotes about the superintendent of the Kansas City, Missouri Schools and others, failed to really introduce the secondary schools. In fact, only one new character, Augustus F. Nightingale, superintendent of the Chicago Public School System remained a constant actor, VanOverbeke's story, primarily through his role on the Committee on College Entrance Requirements.

Although VanOverbeke provided thoughtful scholarship in a field thirsting for policy research, his analysis lacked detailed substance in his discussion on the Carnegie Unit. Certainly he highlights how quickly the development of the Unit helped standardize schools at a more national level, yet he failed to discuss detailed explanations of why. One wonders if the discussions of standardized schooling of the previous 30 years all of the sudden exploded with passion, or did the incentive to receive pension funds play a dominant role. If the latter, it begs a discussion of how money and funds played into policy development and the creation of accrediting systems as a whole. Were colleges losing money or gaining by eliminating preparatory departments? Did these shifts stem from idealistic dreams or real fiscal needs?

As policy analysis gains more popularity in the academic world, VanOverbeke provides a gateway for policy history in an era rich with interest. The writing is lucid, and the message was clear: higher education sits at the top of the system. Even today as we wrestle with P-16, we see challenges to this idea.

Tucker Slosburg Vanderbilt University, Nashville USA 